\title{
Pengaruh Model Pembelajaran Inkuiri Terbimbing terhadap Literasi Sains Siswa Kelas V SD
}

\author{
Ranti Nur Fa'idah ${ }^{1}$, Supriyono Koes $\mathrm{H}^{2}$, Susriyati Mahanal ${ }^{3}$ \\ ${ }^{1}$ Pendidikan Dasar-Universitas Negeri Malang \\ ${ }^{2}$ Pendidikan Fisika-Universitas Negeri Malang \\ ${ }^{3}$ Pendidikan Biologi-Universitas Negeri Malang
}

\section{INFO ARTIKEL}

\section{Riwayat Artikel:}

Diterima: 10-05-2019

Disetujui: 17-12-2019

Kata kunci:
scientific literacy;
guided inquiry;
elementary student;
literasi sains;
inkuiri terbimbing;
siswa SD

siswa $S D$

\author{
Alamat Korespondensi: \\ Ranti Nur Fa'idah \\ Pendidikan Dasar \\ Universitas Negeri Malang \\ Jalan Semarang 5 Malang \\ E-mail: rantifaidah@gmail.com
}

\section{ABSTRAK}

\begin{abstract}
Scientific literacy is a skill that is very important and must be possessed by students. A person with good scientific literacy will be able to survive in the XXI century. In the learning process students are weak in interpreting information so that students have difficulty or cannot make conclusions. Scientific literacy by using initial ability moderator variables in the high category and low category and their interactions in fifth grade students of SD Tanjung Rejo 2 Malang. The results of the pretest and posttest were tested differently with the help of SPSS. The results showed there were significant differences in the increase in scientific literacy.
\end{abstract}

\begin{abstract}
Abstrak: Literasi sains adalah keterampilan yang sangat penting dan harus dimiliki oleh siswa. Seseorang dengan literasi sains yang baik akan mampu bertahan di abad XXI. Pada proses pembelajaran, siswa dianggap lemah dalam mengintepretasikan informasi sehingga siswa kesulitan atau tidak dapat membuat kesimpulan. Variabel moderator kemampuan awal pada kategori tinggi dan kategori rendah serta interaksinya pada siswa kelas V SD Tanjung Rejo 2 Malang. Hasil pretes dan postes dilakukan uji beda dengan bantuan SPSS. Hasil penelitian menunjukkan terdapat perbedaanperbedaan signifikan peningkatan literasi sains.
\end{abstract}

Kemajuan sains dan teknologi saat ini tidak dapat ditolak dan memiliki dampak positif maupun negatif. Kemajuan ini berpengaruh pada kehidupan masyarakat (Piliang, 2014). Kondisi kemajuan teknologi akan memiliki dampak negarif yang jauh lebih besar jika tanpa dibekali pengetahuan sains yang kuat. Kondisi seperti itu dapat diantisipasi dengan membentuk masyarakat yang memiliki ide-ide ilmiah, kemampuan intelektual, kreativitas, penalaran dan kepedulian terhadap lingkungan masyarakat (Rahayu, 2014; Holbrook \& Rannikmae, 2009). Antisipasi ini harus mulai diberikan mulai sejak kecil termasuk pada level pendidikan sekolah dasar. Siswa di sekolah dasar perlu dibekali pemahaman sains dan teknologi yang kuat untuk mampu mengantisipasi dampak negatif dari berkembangnya sains dan teknologi. Dengan pemahaman sains yang kuat, siswa dapat memahami interaksi sains, teknologi, dan masyarakat dengan baik (Abidin et al., 2017).

Literasi sains mengarah pada sikap sains. Literasi sains merupakan kemampuan esensial yang harus dimiliki manusia untuk mampu mengorganisasi, menganalisis, dan menginterpretasikan setiap informasi yang diperoleh dengan baik (Widayoko et al., 2018). Seseorang dengan literasi sains yang baik akan tanggap terhadap lingkungan sekitar serta interaksinya antara sains, teknologi, dan masyarakat. Literasi sains merupakan kemampuan yang dimiliki siswa untuk mengaitkan peristiwa dan teknologi secara kompleks pada era globalisasi dengan pemahaman sains (OECD, 2013). Seseorang yang berliterasi dapat menjelaskan fenomena di sekitar secara ilmiah dengan perspektif sains (Abidin et al., 2017; Seah, 2015; Braaten \& Windschiti, 2011). Berdasarkan hasil PISA 2015 menunjukkan bahwa literasi sains siswa Indonesia masih tergolong rendah. Secara umum, siswa di Indonesia masih lemah menyatakan penjelasan ilmiah secara jelas, dan memahami secara eksplisit dengan bukti yang diberikan (OECD, 2016). Selain itu, siswa masih kesulitan dalam menyusun penjelasan ilmiah dengan tepat, meskipun telah dilakukan pembelajaran yang melibatkan penjelasan ilmiah (Plummer \& Krajcik, 2010; Yao, Guo, \& Neuman, 2016).

Rendahnya literasi sains juga diakibatkan oleh kurangnya kesiapan siswa dalam mengikuti pembelajaran. Kesiapan mengikuti pembelajaran dapat dimiliki siswa pada pengembangan mental dan pengetahuan prasyarat yang sudah dimiliki dengan melibatkan pengalaman atau pemahaman pengetahuan sebelumnya (Ruseffendi, 2004). Kesiapan siswa dalam mengikuti pembelajaran dapat diartikan dengan kemampuan awal siswa. Kemampuan awal siswa yang dipadukan melalui pengetahuan kekurangan pengetahuan awal tidak memungkinkannya untuk maju (Almuntasheri et al., 2016). Kemampuan awal siswa yang melalui pengetahuan sebelumnya dengan pengetahuan baru akan lebih baik. Pengetahuan awal merupakan hal 
penting untuk mengetahui seberapa besar informasi atau pengetahuan siswa setelah belajar untuk dijadikan sebagai tolak ukur keberhasilan pembelajaran. Berbagai permasalahan terkait rendahnya literasi sains menjadi penentu langkah dalam membenahi pembelajaran yang akan dilakukan kedepannya. Pembekalan dalam bentuk proses pembelajaran kepada siswa supaya memiliki literasi sains yang baik sangat diperukan. Salah satunya dengan pembelajaran yang mampu membuat siswa memahami apa yang sedang dipelajarinya (Abidin et al., 2017; Ngalimun, 2018). Pembelajaran yang mampu mengontekstualkan pengetahuannya melalui percobaan maupun penyelidikan.

Model IT aktivitasnya berdasarkan pada kegiatan penyelidikan. Model ini berbasis penyelidikan bidang sains di sekolah dasar melalui bimbingan guru (Nugroho et al., 2012). Model pembelajaran inkuiri memiliki prinsip mengajak siswa melatih memecahkan masalah sendiri dengan aktivitas melalui penyelidikan pengetahuan (Kemdikbud, 2014; Ngalimun, 2018). Hal ini dapat dilihat dari sintaks dari kegiatan pembelajaran eksperimen, presentasi, mengomunikasikan, dan membuat kesimpulan (Eggen \& Kauchak, 2012).

Model inkuiri terbimbing terbukti mampu meningkatkan berbagai macam keterampilan yang harus dimiliki siswa. Beberapa hasil penelitian menyebutkan bahwa model pembelajaran inkuiri terbimbing dapat melengkapi konsep pengetahuan siswa, dengan keterampilan berpikir kritis, dan kreatif, keterampilan berkomunikasi, bekerja dalam kelompok, dan kemampuan siswa dalam mengevaluasi diri (Gormally et al., 2015). Model inkuiri terbimbing dapat meningkatkan keterampilan menemukan bukti-bukti yang dilakukan oleh siswa dengan litrasi sains, serta memiliki dampak postif pada kemampuan awal siswa kelas VII (Ngertini, 2013). Pemberian pengalaman langsung dengan cara IT (Yuliati \& Yuyun, 2017). Keaktifan atau proses kerja inkuiri terbimbing dalam mengikuti proses pembelajaran diperlukan guru sebagai fasilitator siswa dalam memahami materi yang dipelajari. Tujuan model pembelajaran inkuiri terbimbing yaitu mengembangkan sikap dan keterampilan siswa berlatih memecahkan masalah sendiri dengan bimbingan guru (Ngalimun, 2018). Memecahkan permasalahan melalui kegiatan penyelidikan merupakan salah satu dari unsur pembelajaran kontekstual. Pembelajaran kontekstual dengan memecahkan permasalahan sehari-hari merupakan salah satu jabaran aspek kompetensi literasi sains. Komponen penyelidikan pada inkuiri terbimbing diharapkan mampu meningkatkan literasi sains siswa.

\section{METODE}

Penelitian faktorial $2 \times 2$. Tujuan penelitian quasi experiment untuk mengetahui perbedaan kedua kelas. Untuk rancangan pada penelitian ini disajikan pada tabel 1 .

Tabel 1. Rancangan Penelitian Quasi Eksperiment Faktorial

\begin{tabular}{lcc}
\hline \multirow{2}{*}{ Pengetahuan Awal (B) } & \multicolumn{2}{c}{ Model Pembelajaran(A) } \\
\cline { 2 - 3 } & Inkuiri Terbimbing (A1) & Direct Instruction $\left(\mathrm{A}_{2}\right)$ \\
\hline Pengetahuan Awal Rendah $\left(\mathrm{B}_{1}\right)$ & $\mathrm{A}_{1} \mathrm{~B}_{1}$ & $\mathrm{~A}_{2} \mathrm{~B}_{1}$ \\
Pengetahuan Awal Tinggi $\left(\mathrm{B}_{2}\right)$ & $\mathrm{A}_{1} \mathrm{~B}_{2}$ & $\mathrm{~A}_{2} \mathrm{~B}_{2}$ \\
\hline
\end{tabular}

Keterangan:

$\mathrm{A}_{1} \mathrm{~B}_{1}=$ Pembelajaran inkuiri terbimbing pada siswa berpengetahuan awal rendah

$\mathrm{A}_{2} \mathrm{~B}_{1}=$ Pembelajaran direct instruction pada siswa berpengetahuan awal rendah

$\mathrm{A}_{1} \mathrm{~B}_{2}=$ Pembelajaran inkuiri terbimbing pada siswa berpengetahuan awal tinggi

$\mathrm{A}_{2} \mathrm{~B}_{2}=$ Pembelajaran direct instruction pada siswa berpengetahuan awal tinggi

(Gall et al., 2003)

Semua siswa kelas V SD Negeri Tanjung Rejo 2 Malang sebagai sasaran populasi dengan jumlah siswa masingmasing kelas 30 siswa dalam dua kelas. Penelitian ini menggunakan metode cluster sampling yaitu dengan mengundi semua kelas yang ada. Pengambilan data dilakukan dengan tes. Tes dilakukan dua kali. Tes pertama sebelum dilakukan pembelajaran. Hasil tes pertama (tes kemampuan awal) digunakan untuk mengelompokkan siswa ke dalam kategori siswa dengan kemampuan awal tinggi dan rendah. Hasil tes kedua (tes literasi sains) dilakukan uji prasyarat normalitas dan homogenitas. Pengujian hipotesis menggunakan ANAVA dua jalur.

Pengujian hipotesis kemampuan awal maupun literasi sains dilakukan menggunakan anava dua jalur dengan bantuan SPSS. Berikut merupakan jabaran hipotesis dari penelitian.

a. Pengujian Hipotesis Pertama

Ho: Tidak terdapat perbedaan literasi sains antara siswa yang belajar melalui model inkuiri terbimbing dan siswa yang belajar melalui model direct instruction.

Ha: Terdapat perbedaan literasi sains antara siswa yang belajar melalui model inkuiri terbimbing dan siswa yang belajar melalui model direct instruction. 
b. Pengujian Hipotesis Kedua

Ho: Tidak terdapat pengaruh literasi sains antara siswa berkemampuan awal tinggi dan rendah.

Ha: Terdapat pengaruh literasi sains antara siswa berkemampuan awal tinggi dan rendah.

c. Pengujian Hipotesis Ketiga

Ho: Tidak terdapat pengaruh interaksi antara kemampuan awal dan model pembelajaran inkuiri terbimbing terhadap literasi sains siswa kelas V SD.

Ha: Terdapat pengaruh interaksi antara kemampuan awal dan model pembelajaran inkuiri terbimbing terhadap literasi sains siswa kelas V SD.

\section{HASIL}

\section{Data Kemampuan Awal}

Data kemampuan awal diperoleh sebelum proses pembelajaran dimulai. Subjek penelitian dilakukan pada dua kelas yang setiap kelas menggunakan model pembelajaran berbeda. Pembuktian ini dideskripsikan pada tabel 2 .

Tabel 2. Deskripsi Data Kemampuan Awal Tinggi dan Rendah

\begin{tabular}{lccc}
\hline \multicolumn{1}{c}{ Kelas } & Rata-rata & N & Rata-rata Kelas \\
\hline Eksperimen Kemampuan Awal Tinggi & 65,0 & 17 & 56,25 \\
Eksperimen Kemampuan Awal Rendah & 47,5 & 17 & 54.95 \\
Kontrol Kemampuan Awal Tinggi & 62,4 & 17 & \\
Kontrol Kemampuan Awal Rendah & 47,5 & 17 & \\
\hline
\end{tabular}

\section{Data Literasi Siswa}

Kemampuan literasi sains siswa pada penelitian ini diukur dengan tujuan. Literasi sains diperoleh dari tes soal literasi sains yang dilakukan setelah semua perlakuan selesai. Soal tes literasi sains terdiri dari 10 soal pilihan ganda.

Tabel 3. Deskripsi Data Literasi Sains Berdasarkan Kemampuan Awal

\begin{tabular}{lccc}
\hline \multicolumn{1}{c}{ Kelas } & Rata-rata & N & Rata-rata Kelas \\
\hline Eksperimen Kemampuan Awal Tinggi & 85,0 & 17 & 78,75 \\
Eksperimen Kemampuan Awal Rendah & 72,5 & 17 & 72,6 \\
Kontrol Kemampuan Awal Tinggi & 77,5 & 17 & \\
Kontrol Kemampuan Awal Rendah & 67,7 & 17 & \\
\hline
\end{tabular}

\section{Data Hasil Uji Hipotesis}

Selisih antara pretes-postes pada masing-masing kelas. Pada penelitian ini menggunakan uji normalitas KolmogrovSmirnov Test. Uji homogenitas dilakukan dengan Levene's Test. Kedua uji tersebut dilakukan dengan bantuan SPSS. Nilai pretes-postes kelas eksperimen sebesar $1.638>0.05$ dan pada kelas kontrol sebesar $1.110>0.05$, maka data pada kedua kelas terdistribusi normal.

Tabel 4. Uji Normalitas

\begin{tabular}{lccc}
\hline & \multicolumn{3}{c}{ Kolmogrov -Smirnov ${ }^{\boldsymbol{a}}$} \\
\cline { 2 - 4 } & Sig. data & Sig. & Keterangan \\
\hline Kelas Eksperimen & 1.638 & 0.05 & Normal \\
Kelas Kontrol & 1.110 & & Normal \\
\hline
\end{tabular}

Tabel 5. Uji Homogenitas

\begin{tabular}{lccc}
\hline & Sig. Uji Levene & Sig. & Keterangan \\
\hline Kelas Eksperimen & 0.174 & 0.05 & Homogen \\
Kelas Kontrol & 0.118 & & Homogen \\
\hline
\end{tabular}

Berdasarkan data pada tabel 5 diperoleh nilai signifikansi selisih antara nilai pretes-postes kelas mendapati ratarata0.174 > 0.05 dan pada kelas control $0.118>0.05$, data kedua kelas homogen. Berdasarkan prsayarat statistiknya kedua kelas yang terdiri dari kemampuan awal dan hasil tes literasi sains terdistribusi normal dan homogen. Statistik yang digunakan untuk melakukan uji hipotesis adalah jenis uji statistik parametrik. 


\section{Pengujian Hipotesis}

Pengujian hipotesis kemampuan awal maupun literasi sains dilakukan menggunakan anava dua jalur dengan bantuan SPSS. Hasil uji hipotesis dapat dilihat pada tabel 6. Pengujian hipotesis kemampuan awal maupun literasi sains dilakukan menggunakan anava dua jalur.

Tabel 6. Ringkasan Hasil Uji Anava Dua Jalur

\begin{tabular}{lc}
\hline \multicolumn{1}{c}{ Sumber Analisis } & Sig. \\
\hline Kelas & 0.000 \\
Kemampuan awal siswa & 0.122 \\
Kelas * Kemampuan awal siswa & 0.183 \\
\hline
\end{tabular}

Berdasarkan hasil uji anava dua jalur pada tabel 6 maka dapat disimpulkan sebagai berikut. Pertama, pengujian hipotesis pertama dapat dilihat dari signifikansi pada baris kelas. Nilai signifikansi $0.000<0.05$ maka Ho ditolak. Kedua, pengujian hipotesis kedua dapat dilihat dari signifikansi pada baris kemampuan awal siswa. Nilai signifikansi $0.122>0.05$ maka Ho diterima. Ketiga, pengujian hipotesis ketiga dapat dilihat dari signifikansi pada baris kelas * kemampuan awal siswa. Nilai signifikansi $0.183>0.05$ maka Ho diterima.

\section{PEMBAHASAN}

Uji hipotesis yang pertama, signifikansi sebesar $0,000<0,05$ yang menunjukkan Ho ditolak. Terdapat perbedaan literasi sains antara siswa yang belajar melalui model IT dan siswa yang belajar melalui model DI. Sejalan dengan penelitian sebelumnya yang menunjukkan bahwa proses pembelajaran inkuiri terbimbing berbasis penyelidikan membantu siswa memiliki kesempatan belajar aktif dengan cara bertahap untuk menanamkan literasi sains bagi siswa (Ngertini, 2013). Penelitian ini menyertakan kemampuan awal sebagai variabel kontrol penelitian. Kemampuan awal siswa dilihat dari hasil pretes yang kemudian dikelompokkan menjadi kategori kemampuan awal tinggi dan rendah. Pengujian hipotesis kedua dapat dilihat dari signifikansi pada baris kemampuan. Dari data pengelompokan kemampuan awal diperoleh hasil bahwa rata-rata kemampuan awal kedua kelas hampir sama, yaitu 56,25 dan 54,95 di kelas kontrol.

Persebaran hasil dikaterogikan tinggi maupun rendah tidak banyak berbeda. Uji hipotesis terkait pengaruh kemampuan awal terhadap literasi sains siswa (hipotesis kedua) memiliki $0.122>0.05$ maka Ho diterima, terdapat pengaruh siswa berkemampuan awal tinggi dan rendah terhadap hasil literasi sains. Hal ini menunjukkan bahwa nilai literasi sains siswa samasama meningkat pada siswa dengan kemampuan awal yang tinggi maupun rendah. Tidak terdapat perbedaan yang signifikan, namun tetap saja terdapat perbedaan literasi sains pada kelompok eksperimen dan kontrol mengalami peningkatan. Kelas eksperimen dengan kemampuan awal tinggi dan rendah memiliki peningkatan literasi lebih tingi dibandingkan dengan kelas kontrol dengan peningkatan KA tinggi maupun rendah (gambar 1).

Pengujian hipotesis ketiga untuk melihat interaksi antara kemampuan awal dan model pembelajaran inkuiri terbimbing terhadap literasi sains secara simultan. Rata-rata signifikansi $0.183>0.05$ yang menyatakan tidak terdapat pengaruh interaksi antara kemampuan awal dan IT di kelas V. Hasil ini menunjukkan bahwa kemampuan awal dan model pembelajaran inkuiri terbimbing tidak memengaruhi secara simultan atau bersamaan. Model inkuiri terbimbing dapat meningkatkan literasi sains siswa tanpa melibatkan variabel kemampuan awal, begitu juga sebaliknya (gambar 1). Secara stastistik, jika dua variabel bebas berpengaruh pararel (Howell, 2011).

Berdasarkan hasil penelitian dengan IT dapat meningkatkan LS siswa. Meningkatnya LS juga dipercaya meningkatkan daya antisipasi dengan membentuk masyarakat yang memiliki ide-ide ilmiah, kemampuan intelektual, kreativitas, penalaran dan kepedulian terhadap lingkungan masyarakat (Rahayu, 2014; Holbrook \& Rannikmae, 2009). Antisipasi dalam menanggapi dampak negatif dari berkembangnya sains dan teknologi. Dengan pemahaman sains yang kuat, siswa dapat memahami interaksi sains, teknologi, dan masyarakat dengan baik (Abidin et al., 2017). Rendahnya literasi sains juga diakibatkan oleh kurangnya kesiapan siswa dalam mengikuti pembelajaran. Kemampuan awal siswa tidak memengaruhi literasi sains siswa secara signifikan. 


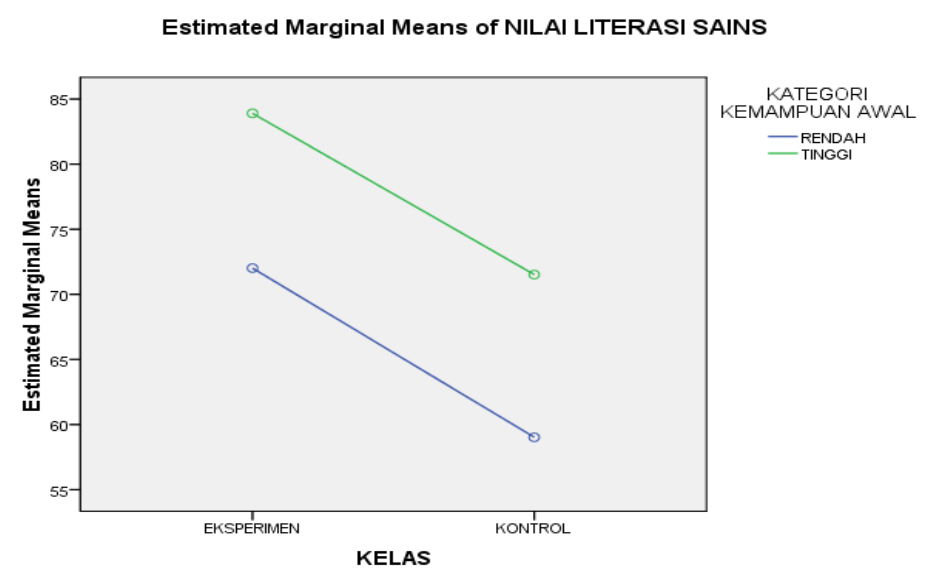

Gambar 1. Interaksi Kelas, Kemampuan Awal, dan Literasi Sains

\section{SIMPULAN}

Kesimpulannya model inkuiri terbimbing dapat meningkatkan literasi sains siswa dan memiliki perbedaan yang signifikan dengan model direct instruction. Kemampuan awal siswa tidak memiliki pengaruh terhadap kenaikan literasi sains, baik siswa dengan kemampuan awal rendah maupun tinggi. Model pembelajaran inkuiri terbimbing dan kemampuan awal siswa tidak memiliki interaksi terhadap literasi sains siswa kelas V SD Tanjung Rejo 2 Malang.

Saran penelitian selanjutnya adalah menyertakan kemampuan awal kategori sedang. Dengan menyertakan kemampuan awal kategori sedang diharapkan dapat memiliki pembanding yang lebih signifikan sehingga interaksi penggunaan model dan variabel kemampuan awal siswa dapat diketahui interaksinya dengan lebih mendetail.

\section{DAFTAR RUJUKAN}

Abidin, Y., Mulyati, T., \& Yunansah, H. (2017). Pembelajaran Literasi. Jakarta: Bumi Aksara.

Almuntasheri, S., Gillies, R. M., \& Wright, T. (2016). The Effectiveness of a Guided Inquiry-based, Teachers' Professional Development Programme on Saudi Students' Understanding of Density. Science Education International, 27(1), 16-39.

Braaten, M., \& Windschiti, M. (2011). Working to Ward a Stronger Conceptualization of Scientific Explanation for Science Education. Science Education, 95(4), 639-669.

Eggen, P., \& Kauchak, D. (2012). Strategi dan Model Pembelajaran: Mengajarkan Konten dan Keterampilan Berpikir, Edisi Keenam. Terjemahan Satrio Wahono. Jakarta: PT Indeks.

Gall, M., Gall, J. ., \& Borg, W. (2003). Educational Research, An Introduction (7th edition). Boston: Pearson Education, Inc.

Gormally, C., Brickman, P., Hallar, B., \& Armstrong, N. (2015). Effects of Inquiry-based Learning on Students' Science Literacy Skills and Confidence. International Journal for the Scholarship of Teaching and Learning, 3(2), 32-43. http://doi.org/https://doi.org/10.20429/ijsotl.2009.030216

Holbrook, J., \& Rannikmae, M. (2009). The Meaning of Scientific Literacy. International Journal of Environmental \& Science Education, 4(3), 275-288.

Howell, D. (2011). Fundamental Statistic for The Behavioral Science, Seventh Edition. Belmont: CA: Wadsworth.

Kemdikbud. (2014). Buku Guru Ilmu Pengetahuan Alam Edisi Revisi. Jakarta: Kemdikbud.

Ngalimun. (2018). Strategi dan Model Pembelajaran (edisi revisi). Yogyakarta: Aswaja Presindo.

Ngertini, N. (2013). Pengaruh Implementasi Model Pembelajaran Inkuiri Terbimbing terhadap Kemampuan Pemahaman Konsep dan Literasi Sains Siswa Kelas X SMA PGRI 1 Amlapura. E-Journal Program Studi Administrasi Pendidikan, 4.

Nugroho, S., Suparmi, \& Sarwanto. (2012). Pembelajaran IPA dengan Metode Inkuiri Terbimbing menggunakan Laboratorium Riil dan Virtuil Ditinjau dari Kemampuan Memori dan Gaya Belajar Siswa. Jurnal Inkuiri, 1(3), 235-244.

OECD. (2016). PISA 2015 Assessment and Analytical Framework Science, Reading, Mathematic, Financial Literacy and Collaborative Problem Solving. Paris: OECD Publishing.

Piliang, Y. M. (2014). Transformasi Budaya Sains dan Teknologi; Membangun Daya Kreativitas. Jurnal Sosioteknologi, 13(2), $76-83$.

Plummer, J. D., \& Krajcik, J. (2010). Building Learning Progression for Celestial Motion: Elementary Levels from an EarthBased Perspective. Journal of Research in Science Teaching, 47(7), 768-787.

Rahayu, S. (2014). Menuju Masyarakat Berliterasi Sains. Harapan dan Tantangan Kurikulum 2013. In Seminar Nasional Kimia dan Pembelajaran (SNKPP) 2014. 
1709 Junal Pendidikan, Vol. 4, No. 12, Bln Dersember, Thn 2019, Hal 1704-1709

Ruseffendi, E. T. (2004). Dasar-dasar Penelitian Pendidikan dan Bidang Non Eksakta Lainnya. Bandung: Tarsito. Seah, L. (2015). Understanding the Conceptual and Language Challenges Encountered by Grade 4 Students when Writing Scientific Explanations. Research in Science Education, 46(3), 413-437.

Widayoko, A., Latifah, E., \& Yuliati, L. (2018). Peningkatan Kompetensi Literasi Sains Siswa SMA dengan Bahan Ajar Terintegrasi STEM pada Materi Impuls dan Momentum. Jurnal Pendidikan: Teori, Penelitian, dan Pengembangan, 3(11), 1463-1467.

Yao, J. X., Guo, Y.-Y., \& Neuman, K. (2016). Toward a Hypthetical Learning Progression of Scientific Explanation. AsiaPasific Science Education, 2(4), 1-17.

Yuliati, Y. (2017). Literasi Sains dalam Pembelajaran IPA. Jurnal Cakrawala Pendas, 3(2), 21-28. 